\title{
Cachexia and protein-energy wasting in children with chronic kidney disease
}

\author{
Robert H. Mak • Wai W. Cheung • Jian-Ying Zhan • \\ Qian Shen • Bethany J. Foster
}

Received: 10 June 2010 /Revised: 13 December 2010 /Accepted: 16 December 2010/Published online: 6 February 2011

(C) The Author(s) 2011. This article is published with open access at Springerlink.com

\begin{abstract}
Children with chronic kidney disease (CKD) are at risk for "cachexia" or "protein-energy wasting" (PEW). These terms describe a pathophysiologic process resulting in the loss of muscle, with or without loss of fat, and involving maladaptive responses, including anorexia and elevated metabolic rate. PEW has been defined specifically in relation to CKD. We review the diagnostic criteria for cachexia and PEW in CKD and consider the limitations and applicability of these criteria to children with CKD. In addition, we present an overview of the manifestations and mechanisms of cachexia and PEW. A host of pathogenetic factors are considered, including systemic inflammation, endocrine perturbations, and abnormal neuropeptide signaling, as well as poor nutritional intake. Mortality risk, which
\end{abstract}

R. H. Mak · W. W. Cheung

Division of Nephrology, Department of Pediatrics,

Rady Children's Hospital, University of California San Diego,

San Diego, CA, USA

J.-Y. Zhan

Children's Hospital, Zhejiang University,

Hangzhou, China

Q. Shen

Children's Hospital, Fudan University,

Shanghai, China

B. J. Foster

Division of Nephrology, Department of Pediatrics,

Montreal Children's Hospital, McGill University Health Centre,

Montreal, Quebec, Canada

R. H. Mak $(\bowtie)$

University of California San Diego,

9500 Gilman Drive, MCO634,

La Jolla, CA 92093-0634, USA

e-mail: romak@ucsd.edu is 100 - to 200 -fold higher in patients with end-stage renal disease than in the general population, is strongly correlated with the components of cachexia/PEW. Further research into the causes and consequences of wasting and growth retardation is needed in order to improve the survival and quality of life for children with CKD.

Keywords Protein energy wasting $\cdot$ Cachexia $\cdot$ Pediatric . Growth failure $\cdot$ Renal failure

\section{Introduction}

Surveys using traditional measures of nutritional status indicate that wasting is common among adults with chronic kidney disease (CKD), with $20-75 \%$ of adults undergoing maintenance dialysis showing some evidence of wasting [1, 2]. At present, only limited data are available on the prevalence of wasting in children with CKD. The accumulation of new evidence and novel thinking in the field of nutrition in CKD has resulted in a recent redefinition of commonly used terms. Wasting caused by factors other than inadequate intake alone is sometimes referred to as cachexia. Cachexia was recently defined as "a complex metabolic syndrome associated with underlying illness and characterized by loss of muscle, with or without loss of fat", by a group of scientists and clinicians participating in a consensus conference on cachexia [3]. This group, which later formed the Society for Cachexia and Wasting Disorders (SCWD) and included participants with diverse backgrounds encompassing many of the diseases states that result in cachexia (such as cancer, human immunodeficiency virus infection, heart failure, CKD, and chronic obstructive pulmonary disease), identified weight loss and growth failure as the most important clinical features of 
cachexia in adults and children, respectively. In the context of CKD, the term protein-energy wasting (PEW) has been proposed by The International Society of Renal Nutrition and Metabolism (ISRNM) to describe a "state of decreased body stores of protein and energy fuels (body protein and fat masses)" [4]. The ISRNM suggested that the term cachexia be reserved for only the most severe forms of PEW. However, there is no obvious distinction between PEW and cachexia from a pathophysiology standpoint; limiting the term cachexia to extreme forms of PEW is perhaps too restrictive.

\section{Cachexia/wasting or malnutrition in CKD}

Wasting, defined as low weight for height [5], was once believed to be invariably caused by inadequate nutritional intake - or malnutrition. As a result, the terms, "wasting", "cachexia", and "malnutrition" were generally used interchangeably, which has caused confusion. Although inadequate nutritional intake may contribute to cachexia or PEW, recent evidence indicates that other factors, including systemic inflammation, endocrine perturbations, and abnormal neuropeptide signaling, may play important roles in wasting in the context of CKD [1,6-10]. The cachexia/ wasting syndrome is characterized by maladaptive responses, including anorexia and increased metabolic rate, and is associated with low serum albumin and loss of body weight; muscle mass is reduced, whereas fat mass is normal or increased. In contrast, malnutrition, defined as the consequence of insufficient food or an improper diet, is characterized by adaptive responses, including hunger, a protective decrease in energy expenditure, and preferential use of fat stores for energy and preservation of lean body mass. Whereas the abnormalities in malnutrition are usually easily reversed by supplying more food or altering the composition of the diet, these approaches are generally unsuccessful in treating cachectic patients [11]. Distinctions between cachexia and malnutrition are summarized in Table 1.

Table 1 Comparison of malnutrition and cachexia/PEW

\begin{tabular}{lll}
\hline Characteristics & Malnutrition & Cachexia/PEW \\
\hline Energy balance & - & - \\
Appetite & $\uparrow$ & $\downarrow$ \\
Metabolic rate & $\downarrow$ & $\uparrow$ \\
Muscle mass & $\approx$ & $\downarrow$ \\
Fat mass & $\downarrow$ & $\approx$ \\
Response to calorie supplementation & + & -
\end{tabular}

PEW, Protein-energy wasting

\section{Clinical features and diagnostic criteria of cachexia/ PEW in CKD}

The diagnostic criteria for cachexia (proposed by the SCWD) and for PEW (proposed by the ISRNM) are similar, but not identical. A weight loss of at least $5 \%$ over 12 months or less or a body mass index (BMI) $<20 \mathrm{~kg} / \mathrm{m}^{2}$ is necessary for the diagnosis of cachexia, plus three of the following five additional criteria: decreased muscle strength, fatigue, anorexia, low fat-free muscle mass, and abnormal biochemistry [including elevated inflammatory markers such as C-reactive protein (CRP) or interleukin (IL)-6, anemia (hemoglobin $<12 \mathrm{~g} / \mathrm{dL}$ ) and hypoalbuminemia]. The proposed criteria for a diagnosis of PEW fall into four distinct categories: (1) biochemical indicators; (2) low body weight, reduced body fat, or weight loss; (3) decreased muscle mass; (4) low protein or energy intake. In contrast to those for PEW, the diagnostic criteria for cachexia emphasize lean mass deficits and functional measures (such as muscle strength and fatigue); in addition, anemia is considered a feature of cachexia, but not of PEW. Table 2, reprinted from the recent consensus paper defining PEW in adult CKD, lists potential PEW markers [4].

Both sets of diagnostic criteria are based largely on evidence in adults and are, therefore, geared towards adults. Modifications to these diagnostic criteria are necessary to improve their applicability to children. In this review, we focus on PEW because this concept was developed to be specifically applicable to CKD patients. The common pathophysiology of PEW and cachexia is acknowledged. The proposed diagnostic criteria for PEW, their limitations, and possible pediatric modifications are discussed.

\section{Biochemical indicators}

Among the biochemical indicators of PEW, low serum albumin stands out as a consistent predictor of mortality in epidemiological studies of both adult [12] and pediatric [13] dialysis patients. However, the specificity of serum albumin as an indicator of PEW in the setting of CKD is not assured [14-21]. Both volume overload and systemic inflammation are associated with depressed serum albumin $[17,18]$. In the absence of inflammatory markers, hypoalbuminemia is not predictive of increased mortality [20, 21]. Hypoalbuminemia was noted by the ISRNM committee to be neither necessary nor sufficient for a diagnosis of PEW. However, given its strong association with mortality, hypoalbuminemia is considered an important biochemical indicator of $\mathrm{PEW}$; its presence should prompt careful assessment of volume status and an investigation for causes of systemic inflammation. Serum prealbumin (also known as transthyretin) has also been recommended as a marker of PEW in dialysis patients; the limitations of prealbumin are 
Table 2 Readily utilizable criteria for the clinical diagnosis of PEW in adults with chronic kidney disease

\section{Criteria for PEW}

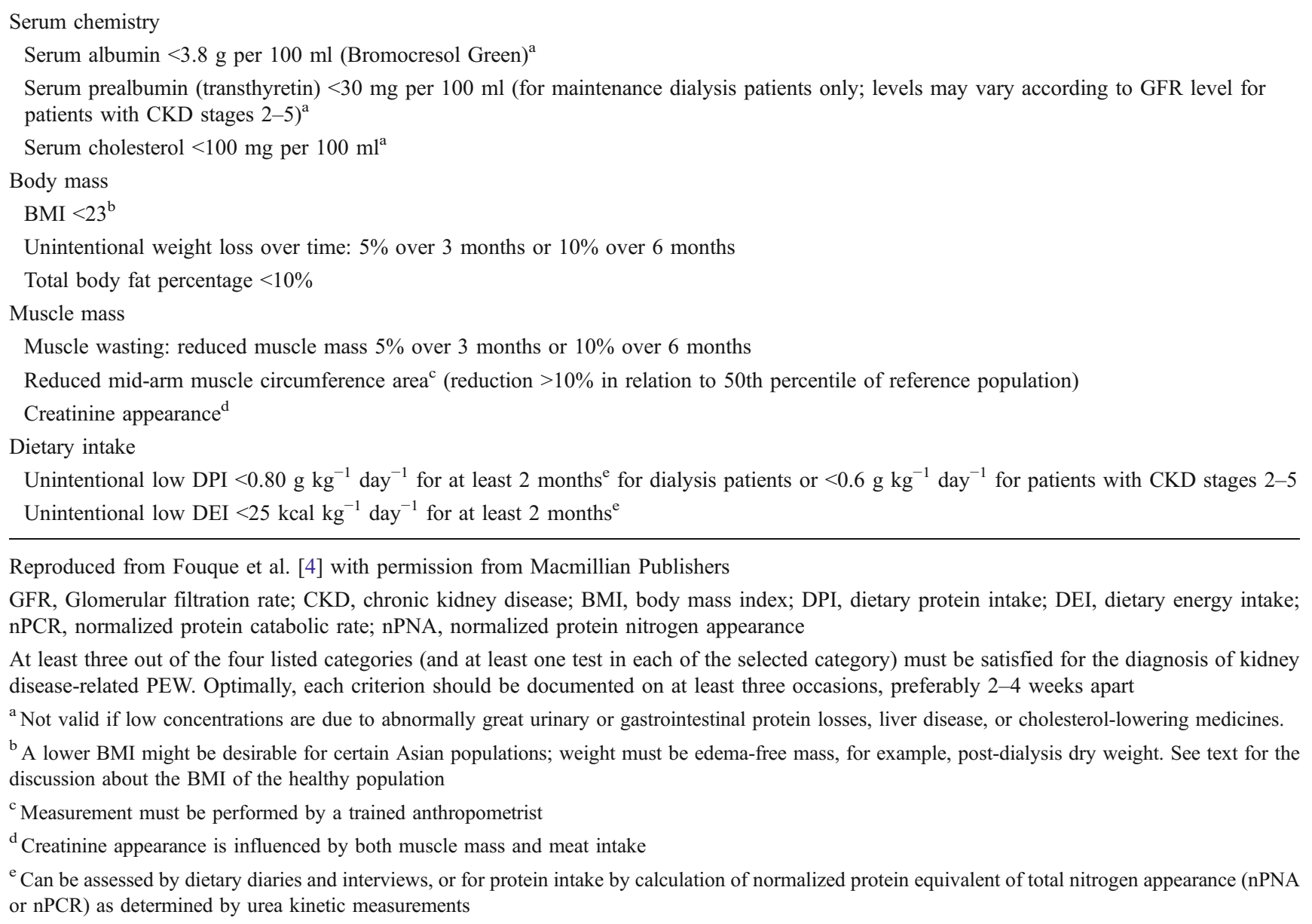

similar to those of albumin. A recent study in adult hemodialysis patients suggested that although baseline serum prealbumin level may not be superior to serum albumin in predicting mortality, prealbumin concentrations $<20 \mathrm{mg} / \mathrm{dL}$ are associated with death risk even in normoalbuminemic patients, and a fall in serum prealbumin over a 6-month period is independently associated with increased death risk [4]. Other nutritional indicators that predict survival in dialysis patients include serum transferrin level [22] and nutritional scoring systems, such as the "subjective global assessment"(SGA) [23] and "malnutrition inflammation score". These scores also correlate with quality of life [24, 25]. Low serum cholesterol has also been proposed as a biochemical indicator of PEW due to its association with mortality in adults with CKD [26]. There are no data on associations between low cholesterol and outcomes in children with CKD; future studies that account for the normal variation in serum cholesterol levels with age [27] and characterize associations between low cholesterol and poor outcomes (death, growth failure) are needed before cholesterol levels can be included in the diagnostic criteria for PEW in children. Circulating inflammatory markers such as CRP [28] and pro-inflammatory cytokines such as IL-6 [29] are persistently elevated in PEW and may be predictive of mortality - but were not included as part of the diagnostic criteria of PEW.

Low body weight, weight loss, or reduced body fat

Evidence of low body weight, reduced body fat, or weight loss are important indicators of PEW in adults. BMI, calculated as weight $(\mathrm{kg})$ divided by height squared $\left(\mathrm{m}^{2}\right)$, is proposed as a method of assessing the appropriateness of body weight. Although BMI gives little information about body composition, it can be a useful means of assessing PEW. BMI is strongly correlated with lean body mass at the low end of the BMI spectrum [30], and low BMI is a consistent predictor of mortality in both adults [31, 32] and children [33] on maintenance dialysis. Because BMI normally changes with growth and development, it must 
be expressed in children as a percentile or $Z$ score relative to age and sex. BMI-for-age percentiles and $Z$ scores can be determined using sex-specific BMI-for-age growth curves from the Centers for Disease Control (updated in 2000) [34] for children $\geq 2$ years of age and the 2006 World Health Organization Child Growth Standards for children $<2$ years of age [35]. In the setting of CKD, it has been suggested that BMI should be expressed relative to height-age (the age at which the child's height would be at the $50 \%$ percentile), rather than chronological age, due to the high prevalence of growth retardation and delayed sexual maturation [36]. Regardless of how BMI is expressed, it is difficult to set a BMI percentile cut-off below which a diagnosis of PEW should be considered for children with CKD. Underweight is defined by the American Centers for Disease Control as a BMI below the 5th percentile for age $[37,38]$. However, this cut-off may not be appropriate as a criterion for PEW in children with CKD. Existing evidence suggests that a higher cut-off may be more appropriate [33], but definitive data are lacking.

An unintentional weight loss or reduction in weight of $\geq 5 \%$ over a 3 -month period or of $\geq 10 \%$ over a 6 month period is suggested as an indicator of PEW in adults, independent of absolute BMI [4]. In children, weight loss is an insensitive indication of PEW; a more appropriate diagnostic criterion would be failure to gain weight appropriately, as evidenced by a crossing-down of BMI percentiles. Linear growth failure has been highlighted as being central to the diagnosis of cachexia [3] and has been associated with a greater mortality risk in infants [39] and children [33] with CKD. However, although growth retardation may be a feature of PEW or cachexia in children, it should be recognized that failure to grow does not always indicate "wasting" in CKD. Growth failure in CKD has several causes, including inadequate calorie intake, delayed sexual maturation, and growth hormone insensitivity. Growth failure may emerge as a necessary, but not sufficient criterion for PEW or cachexia in children with CKD.

A body fat mass of $<10 \%$ of body weight is considered to be an additional criterion for PEW in adults with CKD [4] due to the known association between a total body fat $<10 \%$ and increased mortality risk in adult maintenance dialysis patients [40]. However, like BMI, percentage body fat changes with growth and development in healthy children. Therefore, a single percent body fat cut-off cannot be used as a criterion for PEW in children. In addition, percent body fat may be difficult to interpret in conditions where abnormalities in both fat and lean mass may be present; a decrease in lean mass will result in an apparent increase in percent fat, even if there is no real change in fat mass. Furthermore, studies linking low percent fat to poor outcomes in children with CKD are lacking.
Decreased muscle mass

Reduced muscle mass appears to be the most valid criterion for the presence of PEW in CKD [4], and is also emphasized in the diagnostic criteria for cachexia [3]. Muscle mass, measured using dual energy X-ray absorptiometry (DXA), has been observed to be low in children [41] with CKD. Similar findings have been shown in adults with CKD using near-infrared interactance and bioelectrical impedance [42]. However, such techniques are not practical in the clinical setting. There is currently no clinically useful and reproducible method of measuring muscle mass. Accurate assessment of the adequacy of muscle mass is even more challenging in infants and children, in whom all measures must be normalized for body size and stage of sexual maturation [15]. Indirect measures, such as creatinine appearance (estimated by quantification of creatinine in a 24-h urine collection and in the collected spent dialysate), have been proposed as an index of muscle mass in adults with CKD [4]. However, reference values for creatinine appearance are not available for children, making interpretation impossible at present.

\section{Low protein or energy intake}

Diminished appetite (anorexia), one of the suggested criteria for PEW (and for cachexia), has been associated with increased mortality in adult dialysis patients [43]. Anorexia is a common feature of CKD in infants and is the primary reason for growth failure in this group [44-47]. Poor growth due to inadequate intake has been observed in infants with a glomerular filtration rate (GFR) as high as $70 \mathrm{ml} \mathrm{min}^{-1} 1.73$ $\mathrm{m}^{-2}$ [44]. The prevalence of anorexia among children with CKD beyond infancy is unknown. There is ample evidence to support the effectiveness of supplemental calories in promoting growth in children with CKD up to about 2 years of age [48]. However, calorie intake is generally appropriate for body size in older children with CKD, and there is no evidence that supplemental calories promote growth in the older age group [49]

The validity of the proposed diagnostic criteria for PEW are as yet unconfirmed, even for adults. Nonetheless, it would be useful to develop analogous consensus criteria specifically for infants and children, which could then be validated in prospective, longitudinal studies.

\section{Pathophysiology of cachexia/PEW syndrome in CKD}

The pathophysiology of cachexia/PEW syndrome in CKD is multifactorial; Fig. 1 provides an overview. For the purpose of this review, we will focus on three major features: anorexia, increased energy expenditure, and muscle wasting. 


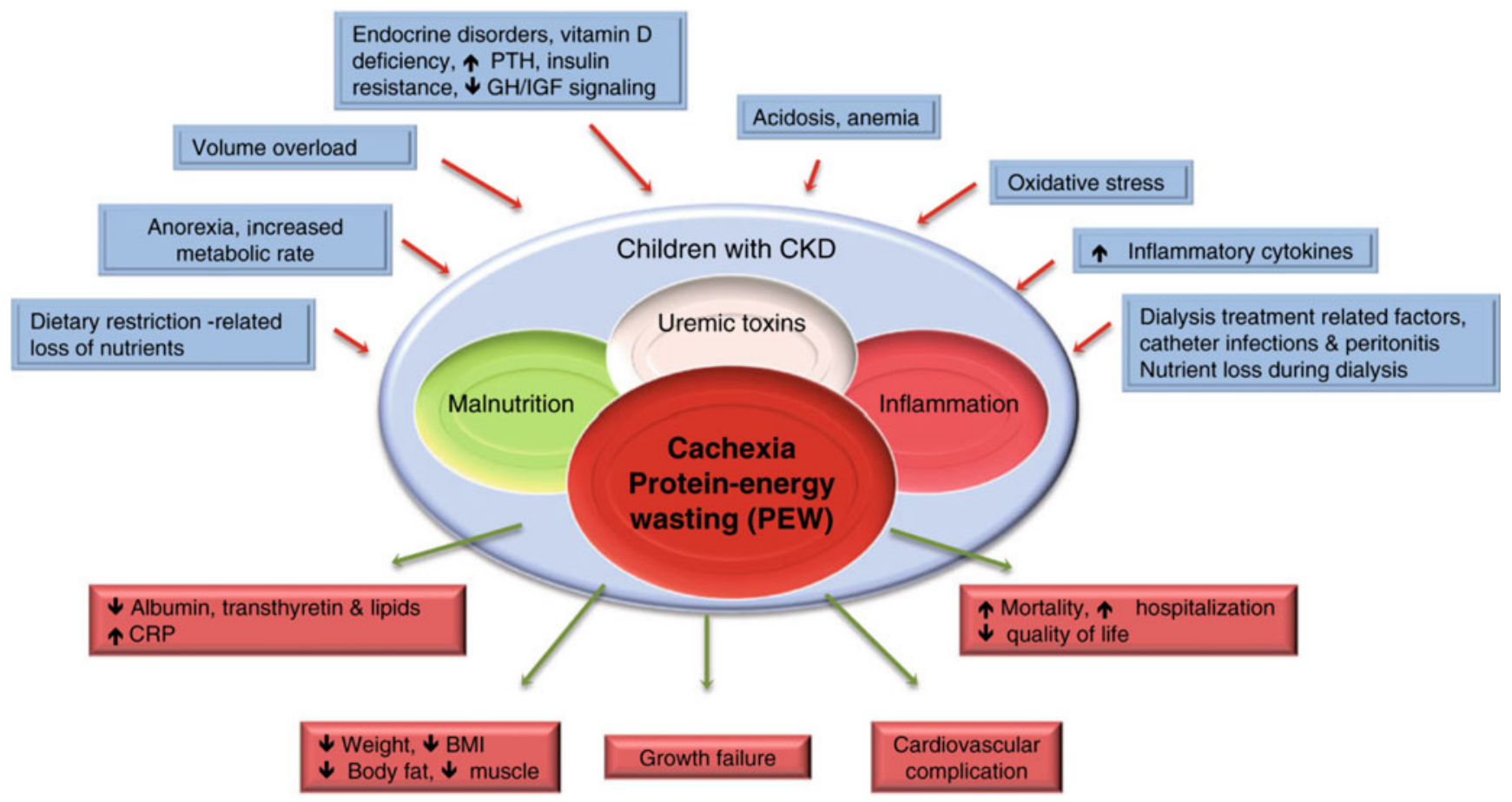

Fig. 1 Schematic representation of the causes and manifestations of the protein-energy wasting $(P E W)$ syndrome in chronic kidney disease $(C K D)$. $G H$ Growth hormone, IGF insulin-like growth factor, PTH parathyroid hormone. Modified from Fouque et al. [4], reprinted with permission from Macmillian Publishers

The kidney also degrades ghrelin. However, total ghrelin levels are not consistently elevated in CKD, despite the decreased degradation of ghrelin by the kidney [53,60]. Whereas in some studies elevated ghrelin levels were found in dialysis patients, in other studies, the levels were normal or even low [61-63]. Multiple confounding factors may contribute to these seemingly contradicting findings. The two major forms of circulating ghrelin are acylated $(<10 \%)$ and des-acyl ghrelin [64, 65]. Acylated ghrelin promotes food intake while des-acyl ghrelin induces negative energy balance. Most investigators used the traditional radioimmunoassay method to quantify total (acylated plus des-acyl) ghrelin. However, only des-acyl ghrelin levels were elevated in CKD patients compared with individuals with normal renal function. Elevated des-acyl ghrelin has been implicated in CKD-related anorexia [65]. Age, sex, and nutritional status may also influence plasma ghrelin levels [59, 62, 66]. Most studies of CKD patients did not account for abnormalities in nutritional status. Furthermore, nutrients introduced during dialysis (i.e., glucose, amino acids) may also influence plasma ghrelin levels [67]. Future longitudinal studies, in which changes in serum acyl- and des-acyl ghrelin levels (measured using enzyme-linked immunosorbent assay) [68] and concomitant nutritional status are measured over time, are needed to determine the pathophysiologic role of ghrelin in CKD [69]. appetite are obscured in this population [59]. 
Increased energy expenditure

Increased energy expenditure despite inadequate calorie intake is an important feature of cachexia often observed in CKD. Wang et al. [70] reported elevated resting energy expenditure (REE) in adults on peritoneal dialysis, with REE predicting subsequent mortality. However, the significance of REE in predicting mortality was gradually reduced when additional adjustment was made for CRP, serum albumin, and residual GFR in a stepwise manner [70].

Increased REE in CKD may be due to increased activity of mitochondrial uncoupling proteins (UCPs). UCPs, a family of mitochondrial anion transporters, regulate ATP synthesis and the production of reactive oxygen species. Uncoupling of mitochondrial electron transporter chain activity from the phosphorylation of ADP results in thermogenesis [71]. UCP-1 and UCP-3 are key regulators of energy expenditure in rodents [72] and humans [73]. In a previous investigation, we showed that uremic mice had a higher basal metabolic rate and associated elevations in brown adipose tissue UCP-1 mRNA and protein and UCP3 protein content compared with pair-fed control mice [74].

\section{Muscle wasting}

There is evidence that inflammation is an important cause of muscle wasting in CKD. In animal studies, infusion of cytokines, such as TNF- $\alpha$, IL-6, IL- $1 \beta$, and interferongamma (IFN- $\gamma$ ), enhanced muscle protein degradation via the NFK $\beta$ pathway $[75,76]$, whereas neutralization of these factors by genetic or pharmacological approaches attenuates muscle wasting. Inflammation activates the ubiquitinproteasome system, which leads to increased muscle breakdown [77] that is not countered by a corresponding upregulation of anabolic pathways [78] (Fig. 2).

$N F K \beta$ is a central integration molecule for proinflammatory signals and a regulator of related target genes. As such, NFK $\beta$ activation is required for cytokineinduced loss of skeletal muscle proteins. TNF- $\alpha$ induces NFK $\beta$ activation, which attenuates insulin-stimulated protein synthesis, leading to muscle wasting. TNF- $\alpha$ also inhibits myocyte differentiation through $\mathrm{NFK} \beta$ activation, further promoting muscle wasting. Activation of $\mathrm{NFk} \beta$ signaling is sufficient to induce significant muscle atrophy, as measured by increases in amino acid excretion and tyrosine turnover in isolated muscles [79]. Activation of NFK $\beta$ is controlled by IK $\beta$ kinase complex (IKK). Furthermore, inflammation may suppress insulin signaling and increase the production of glucocorticoids [51].

Myostatin and insulin-like growth factor 1 (IGF-1) represents yin and yang signaling pathways in the pathogenesis of muscle wasting in CKD [80]. Myostatin, which

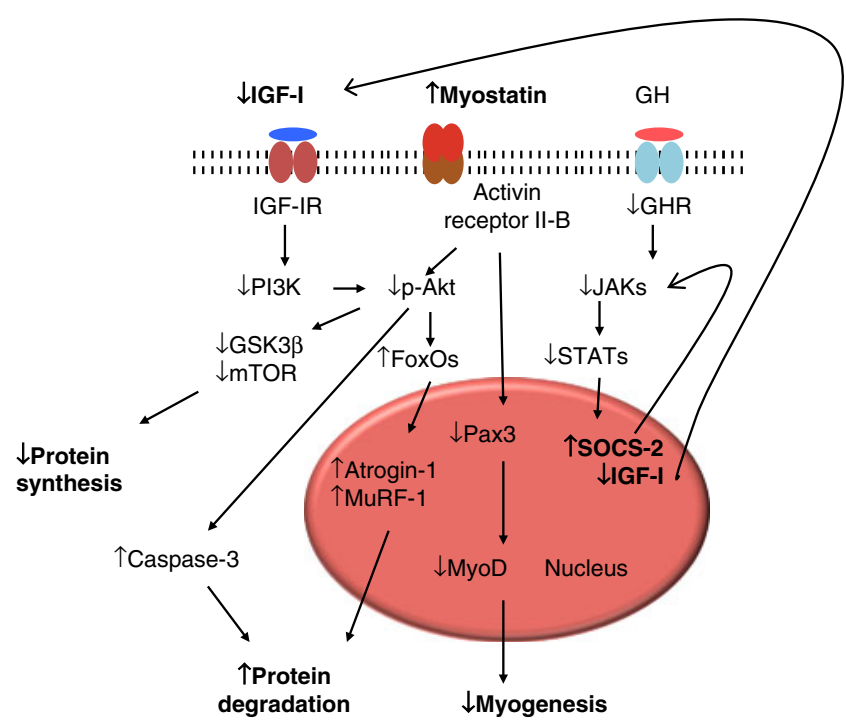

Fig. 2 Pathophysiology of muscle wasting in CKD. Reprinted from Cheung et al. [78] with permission from Macmillian Publishers

circulates in a latent form that can be activated by acid treatment, downregulates skeletal muscle mass. Myostatindeficient mice show muscle fiber hyperplasia and hypertrophy, resulting in a marked increase in muscle mass [81]. In contrast, systemic overexpression of myostatin in adult mice induced profound muscle and fat loss analogous to that seen in human cachexia syndromes [82]. Thus, myostatin may act as a muscle "chalone," a term proposed over 30 years ago for a circulating protein that inhibits the growth of a particular tissue and thereby maintains appropriate tissue mass [82].

IGF-1 is also essential for the growth and maintenance of skeletal muscle mass. Both IGF-1 and IGF-1 receptor knockout mice were significantly smaller than their control littermates and had reduced muscle mass, whereas overexpressed IGF-1 transgenic mice showed increased muscle mass [83]. Growth retardation and muscle wasting in CKD are associated with perturbations in the growth hormoneIGF-1 axis [84]. Treatment of children with CKD with recombinant human $\mathrm{GH}$ has been identified as an important and significant determinant of higher muscle mass relative to height [41]. This finding emphasizes the potential importance of IGF-1 in the pathogenesis of muscle wasting in CKD. The balance between expression of myostatin and IGF-1 is important in regulating muscle mass in CKD [80].

\section{Conclusion}

Many questions remain regarding the description, classification, and treatment of PEW or cachexia in children with CKD. Can nutritional intervention improve the biochemical and clinical disorders related to PEW? If therapeutic interventions 
are effective at improving indicators of PEW, will clinical outcomes also improve? Our new understanding of the pathophysiology of PEW in CKD has the promise of novel therapeutic strategies. Novel therapies, such as ghrelin agonists [85] and melanocortin antagonists [51], are potentially exciting new strategies. However, most of the information is currently at the experimental level and awaits confirmation by randomized controlled clinical trials in children with $\mathrm{CKD}$-associated cachexia/PEW syndrome.

Acknowledgments RHM is supported by National Institute of Health(NIH) U01 DK-03-012 grant. WWC is supported by a young investigator award from the National Kidney Foundation. BJF was supported by the Fonds de la recherche en santé du Québec (FRSQ).

Conflict of interest statement The authors declare no conflict of interests.

Open Access This article is distributed under the terms of the Creative Commons Attribution Noncommercial License which permits any noncommercial use, distribution, and reproduction in any medium, provided the original author(s) and source are credited.

\section{References}

1. Kalantar-Zadeh K, Ikizler TA, Block G, Avram MM, Kopple JD (2003) Malnutrition-inflammation complex syndrome in dialysis patients: causes and consequences. Am J Kidney Dis 42:864-881

2. Kopple JD (1997) McCollum Award Lecture, 1996: proteinenergy malnutrition in maintenance dialysis patients. Am J Clin Nutr 65:1544-1557

3. Evans WJ, Morley JE, Argiles J, Bales C, Baracos V, Guttridge D, Jatoi A, Kalantar-Zadeh K, Lochs H, Mantovani G, Marks D, Mitch WE, Muscaritoli M, Najand A, Ponikowski P, Rossi Fanelli F, Schambelan M, Schols A, Schuster M, Thomas D, Wolfe R, Anker SD (2008) Cachexia: a new definition. Clin Nutr 27:793-799

4. Fouque D, Kalantar-Zadeh K, Kopple J, Cano N, Chauveau P, Cuppari L, Franch H, Guarnieri G, Ikizler TA, Kaysen G, Lindholm B, Massy Z, Mitch W, Pineda E, Stenvinkel P, Trevinho-Becerra A, Wanner C (2008) A proposed nomenclature and diagnostic criteria for protein-energy wasting in acute and chronic kidney disease. Kidney Int 73:391-398

5. World Health Organization (2010). Nutrition Landscape Information System (NLIS) Country Profile Indicators Interpretation Guide. World Health Organization. Geneva, Available at: http:// whqlibdoc.who.int/publications/2010/9789241599955_eng.pdf

6. Mak RH, Cheung W (2007) Cachexia in chronic kidney disease: role of inflammation and neuropeptide signaling. Curr Opin Nephrol Hypertens 16:27-31

7. Mak RH, Cheung W, Cone RD, Marks DL (2006) Mechanisms of disease: cytokine and adipokine signaling in uremic cachexia. Nat Clin Pract Nephrol 2:527-534

8. Mitch WE (2002) Insights into the abnormalities of chronic renal disease attributed to malnutrition. J Am Soc Nephrol 13(Suppl 1): S22-S27

9. Mitch WE (2002) Malnutrition: a frequent misdiagnosis for hemodialysis patients. J Clin Invest 110:437-439

10. Mitch WE (2006) Proteolytic mechanisms, not malnutrition, cause loss of muscle mass in kidney failure. J Ren Nutr 16:208-211
11. Mak RH, Cheung W (2006) Energy homeostasis and cachexia in chronic kidney disease. Pediatr Nephrol 21:1807-1814

12. Lowrie EG, Lew NL (1990) Death risk in hemodialysis patients: the predictive value of commonly measured variables and an evaluation of death rate differences between facilities. Am J Kidney Dis 15:458-482

13. Wong CS, Hingorani S, Gillen DL, Sherrard DJ, Watkins SL, Brandt JR, Ball A, Stehman-Breen CO (2002) Hypoalbuminemia and risk of death in pediatric patients with end-stage renal disease. Kidney Int 61:630-637

14. Bergstrom J, Lindholm B (1998) Malnutrition, cardiac disease, and mortality: an integrated point of view. Am J Kidney Dis 32:834-841

15. Foster BJ, Leonard MB (2004) Measuring nutritional status in children with chronic kidney disease. Am J Clin Nutr 80:801-814

16. Graf L, Candelaria S, Doyle M, Kaskel F (2007) Nutrition assessment and hormonal influences on body composition in children with chronic kidney disease. Adv Chronic Kidney Dis $14: 215-223$

17. Jones CH, Wells L, Stoves J, Farquhar F, Woodrow G (2002) Can a reduction in extracellular fluid volume result in increased serum albumin in peritoneal dialysis patients? Am J Kidney Dis 39:872-875

18. Kalantar-Zadeh K, Kopple JD (2001) Relative contributions of nutrition and inflammation to clinical outcome in dialysis patients. Am J Kidney Dis 38:1343-1350

19. Kalantar-Zadeh K, Kopple JD, Block G, Humphreys MH (2001) A malnutrition-inflammation score is correlated with morbidity and mortality in maintenance hemodialysis patients.[comment]. Am J Kidney Dis 38:1251-1263

20. Kaysen GA (2000) Malnutrition and the acute-phase reaction in dialysis patients-how to measure and how to distinguish. Nephrol Dial Transplant 15:1521-1524

21. Yeun JY, Levine RA, Mantadilok V, Kaysen GA (2000) CReactive protein predicts all-cause and cardiovascular mortality in hemodialysis patients. Am J Kidney Dis 35:469-476

22. Kalantar-Zadeh K, Kleiner M, Dunne E, Ahern K, Nelson M, Koslowe R (1998) Luft FC (1998) Total iron-binding capacityestimated transferrin correlates with the nutritional subjective global assessment in hemodialysis patients. Am J Kidney Dis 31:263-272

23. Steiber AL, Kalantar-Zadeh K, Secker D, McCarthy M, Sehgal A, McCann L (2004) Subjective global assessment in chronic kidney disease: a review. J Ren Nutr 14:191-200

24. Friedman AN, Fadem SZ (2010) Reassessment of albumin as a nutritional marker in kidney disease. J Am Soc Nephrol 21:223230

25. Rambod M, Bross R, Zitterkoph J, Benner D, Pithia J, Colman S, Kovesdy CP, Kopple JD, Kalantar-Zadeh K (2009) Association of malnutrition-inflammation score with quality of life and mortality in hemodialysis patients: a 5-year prospective cohort study. Am J Kidney Dis 53:298-309

26. Noori N, Kovesdy CP, Dukkipati R, Kim Y, Duong U, Bross R, Oreopoulos A, Luna A, Benner D, Kopple KD, Kalantar-Zadeh K (2010) Survival predictability of fat mass in men and women undergoin maintenance hemodialysis. Am J Clin Nutr 92:1060 1070

27. Benuck I, Gidding SS, Donovan M (1995) Year-to-year variability of cholesterol levels in a pediatric practice. Arch Pediatr Adolesc Med 149(3):292-296

28. Stenvinkel P (2001) Malnutrition and chronic inflammation as risk factors for cardiovascular disease in chronic renal failure. Blood Purif 19:53-61

29. Bologa RM, Levine DM, Parker TS, Cheigh JS, Serur D, Stenzel KH, Rubin AL (1998) Interleukin-6 predicts hypoalbuminemia, hypocholesterolemia and mortality in hemodialysis patients. Am J Kidney Dis 32:107-114 
30. Freeman DS, Ogden CL, Berenson GS, Horlick M (2005) Body mass index and body fatness in childhood. Curr Opin Clin Nutr Metab Care 8:618-623

31. Kalantar-Zadeh K, Abbott KC, Salahudeen AK, Kilpatrick RD, Horwich TB (2005) Survival advantages of obesity in dialysis patients. Am J Clin Nutr 81:543-554

32. Leavey SF, Strawderman RL, Jones CA, Port FK, Held PJ (1998) Simple nutritional indicators as independent predictors of mortality in hemodialysis patients. Am J Clin Nutr 31:997-1006

33. Wong CS, Gipson DS, Gillen DL, Emerson S, Koepsell T, Sherrard DJ, Watkins SL, Stehman-Breen C (2000) Anthropometric measures and risk of death in children with end-stage renal disease. Am J Kidney Dis 36:811-819

34. Kuczmarski RJ, Ogden CL, Guo SS, Grummer-Strawn LM, Flegal KM, Mei Z, Wei R, Curtin LR, Roche AF, Johnson CL (2002) 2000 CDC growth charts for the United States: methods and development. Vital Health Stat 246:1-19

35. World Health Organization (2006) WHO child growth standards: length/height-for-age, weight-for-age, weight-for-height and body mass index-for-age: methods and development. World Health Organization, Geneva. Available at: http://www.who.int/childgrowth/ publications/technical_report_pub/en/index.htm

36. No authors listed (2000) Clinical practice guidelines for nutrition in chronic renal failure. K/DOQI. National Kidney Foundation. Am J Kidney Dis 35(6 Suppl 2):S1-S140

37. World Health Organization Expert Committee on Physical Status (1996). The Use and Interpretation of Anthropometry. Physical Status: Report of a WHO Expert Committee: WHO Technical Report Series 854, WHO, Geneva

38. World Health Organization (1995) Physical status: the use and interpretation of anthropometry. WHO Technical Report Series. World Health Organization, Geneva

39. Furth SL, Stablein D, Fine RN, Powe NR, Fivush BA (2002) Adverse clinical outcomes associated with short stature at dialysis initiation: a report of the North American Pediatric Renal Transplant Cooperative Study. Pediatrics 109:909-913

40. Kalantar-Zadeh K (2005) Causes and consequences of the reverse epidemiology of body mass index in dialysis patients. J Ren Nutr 15:142-147

41. Foster BJ, Kalkwarf HJ, Shults J, Zemel BS, Wetzsteon RJ, Thayu M, Foerster DL, Leonard MB (2010) Chronic kidney disease is associated with muscle deficits in children. J Am Soc Nephrol. doi:10.1681/ASN.2010060603

42. Bross R, Chandramohan G, Kovesdy CP, Orepoulos A, Noori N, Golden S, Benner D, Kopple JD, Kalantar-Zadeh K (2010) Comparing body composition assessment tests in long-term hemodialysis patients. Am J Kidney Dis 55:885-896

43. Kalantar-Zadeh K, Block G, McAllister CJ, Humphreys MH, Kopple JD (2004) Appetite and inflammation, nutrition, anemia, and clinical outcome in hemodialysis patients. Am J Clin Nutr 80:299-307

44. Betts P, Magrath G (1974) Growth pattern and dietary intake of children with chronic renal insufficiency. Br Med J 2:189-193

45. Abitbol CL, Zilleruelo G, Montane B, Strauss J (1993) Growth of uremic infants on forced feeding regimens. Pediatr Nephrol 7:173-177

46. Ledermann SE, Shaw V, Trompeter RS (1999) Long-term enteral nutrition in infants and young children with chronic renal failure. Pediatr Nephrol 13:870-875

47. Pollock C, Voss D, Hodson E, Crompton C (2005) The CARI guidelines. Nutrition and growth in kidney disease. Nephrology 10(Suppl 5):S177-S230

48. Mekhali D, Shaw V, Ledermann WE, Rees L (2010) Long term outcome of infants with severe chronic kidney disease. Clin J Am Soc Nephrol 5:10-17

49. Sienna JL, Saqan R, The JC, Frieling ML, Secker D, Cornelius V, Geary DF (2010) Body size in children with chronic kidney disease after gastrostomy tube feeding. Pediatr Nephrol 25:2115-2121
50. Bellisle F, Dartois AM, Kleinknecht C, Broyer M (1995) Alteration of the taste for sugar in renal insufficiency: study in the child. Néphrologie 16:203-208

51. Cheung WW, Paik KH, Mak RH (2010) Inflammation and cachexia in chronic kidney disease. Pediatr Nephrol 25:711-724

52. Mak RH, Cheung W, Cone RD, Marks DL (2006) Leptin and inflammation-associated cachexia in chronic kidney disease. Kidney Int 69:794-797

53. Mak RH, Cheung W, Purnell J (2007) Ghrelin in chronic kidney disease: too much or too little? Perit Dial Int 27:51-55

54. Daschner M, Tonshoff B, Blum WF, Englaro P, Wingen AM, Schaefer F, Wuhl E, Rascher W, Mehls O (1998) Inappropriate elevation of serum leptin levels in children with chronic renal failure. European study group for nutritional treatment of chronic renal failure in children. J Am Soc Nephrol 9:1074-1079

55. Cheung WW, Yu PX, Little BM, Cone RD, Marks DL, Mak RH (2005) Role of leptin and melanocortin signaling in uremiaassociated cachexia. J Clin Invest 115:1659-1665

56. Mak RH, Cheung W (2007) Therapeutic strategy for cachexia in chronic kidney disease. Curr Opin Nephrol Hypertens 16:542-546

57. Rodriguez-Carmona A, Perez Fontan M, Cordido F, Garcia Falcon T, Garcia-Buela J (2000) Hyperleptinemia is not correlated with markers of protein malnutrition in chronic renal failure. A crosssectional study in predialysis, peritoneal dialysis and hemodialysis patients. Nephron 86:274-280

58. Bossola M, Muscaritoli M, Valenza V, Panocchia N, Tazza L, Cascino A, Laviano A, Liberatori M, Lodovica Mousser M, Rossi Fanelli F, Luciani F (2004) Anorexia and serum leptin levels in hemodialysis patients. Nephron Clin Pract 97:c76-c82

59. Stenvinkel P, Lindholm B, Lonnqvist F, Katzarski K, Heimburger O (2000) Increases in serum leptin levels during peritoneal dialysis are associated with inflammation and a decrease in lean body mass. J Am Soc Nephrol 11:1303-1309

60. Cheung WW, Mak RH (2010) Ghrelin in chronic kidney disease. Int J Pept. doi:10.1155/2010/567343

61. Perez-Fontan M, Cordido F, Rodriguez-Carmona A, Peteiro J, Garcia-Naveiro R, Garcia-Buela J (2004) Plasma ghrelin levels in patients undergoing haemodialysis and peritoneal dialysis. Nephrol Dial Transplant 19:2095-2100

62. Szczepanska M, Szprynger K, Mazur B, Zwolinska D, KillisPstrusinska K, Makulska I (2007) Plasma ghrelin levels in children with chronic renal failure on peritoneal dialysis. Perit Dial Int 27:61-66

63. Iglesias P, Diez JJ, Fernandez-Reyes MJ, Codoceo R, Alvarez-Fidalgo P, Bajo MA, Aguilera A, Selgas R (2006) Serum ghrelin concentration in patients with chronic renal failure undergoing dialysis. Clin Endocrinol 64:68-73

64. Hosoda H, Kojima M, Matsuo H, Kangewa K (2000) Purification and characterization of rat des-Gln14-ghrelin, a second endogenous ligand for the growth hormone secretagogue receptor. J Biol Chem 275:21995-22000

65. Hosoda H, Kojima M, Matsuo H, Kangewa K (2000) Ghrelin and des-acyl ghrelin: two major forms of rat ghrelin peptide in gastrointestinal tissue. Biochem Biophys Res Commun 279:909-913

66. Yoshimoto A, Mori K, Sugawara A, Mukovama M, Yahata K, Suganami T, Takaya K, Hosodo H, Kojima M, Kangawa K, Nakao K (2002) Plasma ghrelin and desacyl ghrelin concentration in renal failure. J Am Soc Nephrol 13:2748-2752

67. Perez-Fontan M, Cordido F, Rodriguez-Carmona A, Garcia-Naveiro R, Isidro ML, Villaverde P, Garcia-Buela J (2005) Acute plasma ghrelin and leptin responses to oral feeding or intraperitoneal hypertonic glucose-based dialysate in patients with chronic renal failure. Kidney Int 68:2877-2885

68. Akamizu T, Shinomiya T, Irako T, Fukunaga M, Nakai Y, Kangawa K (2005) Separate measurement of plasma levels in acylated and desacyl ghrelin in healthy subjects using a new direct ELISA assay. J Clin Endocrinol Metab 90:6-9 
69. Ayala ER, Pecoits-Filho R, Heimburger O, Lindholm B, Nordfors L, Stenvinkel P (2004) Associations between plasma ghrelin levels and body composition in end-stage renal disease: a longitudinal study. Nephrol Dial Transplant 19:421-426

70. Wang AY, Sea MM, Tang N, Sanderson JE, Lui SF, Li PK, Woo J (2004) Resting energy expenditure and subsequent mortality risk in peritoneal dialysis patients. J Am Soc Nephrol 15:3134-3143

71. Argiles JM, Busquets S, Lopez-Sorian FJ (2002) The role of uncoupling proteins in pathophysiological states. Biochem Biophys Res Commun 293:1145-1152

72. Hansen ES, Knudsen J (1986) Parallel measurements of heat production and thermogenin content in brown fat cells during cold acclimation of rats. Biosci Rep 6:31-38

73. Rothwell NJ, Stock MJ (1979) A role for brown adipose tissue in diet-induced thermogenesis. Nature 281:31-35

74. Cheung WW, Huo HJ, Markison S, Chen C, Foster AC, Marks DL, Mak RH (2007) Peripheral administration of the melanocortin-4 receptor antagonist NBI-12i ameliorates uremiaassociated cachexia in mice. J Am Soc Nephrol 18:2517-2524

75. Zhang L, Du J, Hu Z, Han G, Delafontaine P, Garcia G, Mitch WE (2009) IL-6 and serum amyloid A synergy mediates angiotensin IIinduced muscle wasting. J Am Soc Nephrol 20:604-612

76. Guttridge DC, Mayo MW, Madrid LV, Wang CY, Baldwin AS Jr (2000) NF-kappaB-induced loss of MyoD messenger RNA: possible role in muscle decay and cachexia. Science 289:23632366

77. Lee SW, Dai G, Hu Z, Wang X, Du J, Mitch WE (2004) Regulation of muscle protein degradation: coordinated control of apoptotic and ubiquitin-proteosome systems by phosphatidylinositol 3 kinase. J Am Soc Nephrol 15:1537-1545

78. Cheung WW, Rosengren S, Boyle DL, Mak RH (2008) Modulation of melanocortin signaling ameliorates uremic cachexia. Kidney Int $74: 180-186$

79. Lin SY, Chen WY, Lee FY, Huang CJ, Sheu WHH (2005) Activation of ubiquitin-proteosome pathway in a rat model with biliary cirrhosis, potential role of TNF- $\alpha$. Am J Physiol Endocrinol Metab 288:E493-E501

80. Mak RH, Rotwein PS (2006) Myostatin and insulin-like growth factors in uremic sarcopenia: the yin and yang in muscle mass regulation. Kidney Int 70:410-412

81. McPherron AC, Lawler AM, Lee SJ (1997) Regulation of skeletal muscle mass in mice by a new TGF- $\beta$ superfamily member. Nature 387:83-90

82. Zimmers TA, Davies MV, Koniaris LG, Haynes P, Esquela AF, Tomkinson KN, McPherron AC, Wolfman NM, Lee SJ (2002) Induction of cachexia in mice by systemically administered myostatin. Science 296:1486-1488

83. Kuninger DT, Rotwein PS (2003) IGF action and skeletal muscle. In: LeRoith D, Zumkeller W, Baxter R (eds) Insulin-like growth factors. Landes Bioscience/Kluwer Academic/Plenum, New York, pp 235-243

84. Mak RH, Cheung WW, Roberts CT Jr (2008) The growth hormone-insulin-like growth factor-I axis in chronic kidney disease. Growth Horm IGF Res 18:17-25

85. Cheung WW, Mak RH (2009) Ghrelin and its analogues as therapeutic agents for anorexia and cachexia in end-stage renal disease. Kidney Int 76:135-137 